\title{
Aplikasi Legalitas Surat Izin Mengemudi (SIM) Berbasis Mobile (Studi Kasus : Polisi Resort Rengat)
}

\author{
Des Suryani1 $^{1}$, Ana Yulianti ${ }^{2}$, Muhammad Zulhelmi ${ }^{3}$ \\ ${ }^{1,2,3}$ Program Studi Teknik Informatika, Fakultas Teknik, Universitas Islam Riau \\ e-mail: ${ }^{1}$ des.suryani@eng.uir.ac.id, ${ }^{2}$ ana.yulianti@eng.uir.ac.id, \\ ${ }^{3}$ muhammad.zulhelmi@gmail.com,
}

\begin{abstract}
Based on act no. 22 year 2009 about traffic and public transportation, then every man who were driving a motor vehicle in the way of is required to have driving license conforming to a type a motor vehicle which was driven by. In this case also will be the criminal sanctions confinement a maximum 1 (one) month or fines to everyone who drove vehicles who could not show driving licenses legitimate. In the process of law enforcement in the way of especially Rengat police precinct would make every effort to know there is still a legality of driving license the rider where had to check the validity period for the rider's driving license. Legality of driving license is still done manually because the industries have not an instrument to prove legality of rider's driving license. In this research have been built an application that can be assisted the police to know legality of the rider's driving license when do the law enforcement on the road. In application is provided by a database that consisting of 7 (seven) that interconnected. Based on testing towards the system were obtained the results of $84 \%$, so that this system should be applied.
\end{abstract}

Keywords : Driving licenses, legality, police

\begin{abstract}
Abstrak
Berdasarkan undang-undang nomor 22 tahun 2009 tentang lalu lintas dan angkutan jalan, maka setiap orang yang mengemudikan kendaraan bermotor di jalan wajib memiliki Surat Izin Mengemudi sesuai dengan jenis kendaraan bermotor yang dikemudikan. Dalam hal ini juga nantinya akan adanya sanksi pidana kurungan paling lama 1 (satu) bulan atau denda kepada setiap orang yang mengemudikan kendaraan bermotor di jalan yang tidak dapat menunjukkan Surat Izin Mengemudi yang sah. Dalam proses penegakkan hukum di jalan khususnya di Polres Rengat masih terdapat kendala untuk mengetahui legalitas Surat Izin Mengemudi (SIM) pengendara dimana harus mengecek masa berlaku dari SIM pengendara. Legalitas SIM masih dilakukan secara manual karena minimnya alat untuk membuktikan legalitas SIM pengendara. Dalam penelitian ini telah dibangun sebuah aplikasi yang dapat membantu pihak kepolisian untuk mengetahui legalitas SIM pengendara pada saat penegakkan hukum di jalan. Dalam aplikasi ini menggunakan sebuah database yang terdiri dari 7 (tujuh) table yang saling berelasi. Berdasarkan pengujian terhadap sistem tersebut diperoleh hasil $84 \%$, sehingga sistem ini layak untuk diterapkan.
\end{abstract}

Kata kunci: Surat Izin Mengemudi, legalitas, polisi

\section{PENDAHULUAN}

Adanya perkembangan Ilmu Pengetahuan Teknologi (IPTEK) yang sangat pesat berpengaruh terhadap perilaku manusia di dalam hidup bermasyarakat dan bernegara yang menjadikannya semakin kompleks. Perilaku yang demikian apabila dipandang dari 
segi hukum tentunya ada perilaku yang sesuai dengan norma dan ada yang bertentangan dengan norma. Perilaku yang sesuai dengan norma tentunya tidak ada masalah, akan tetapi terhadap perilaku yang tidak sesuai dengan norma biasanya menimbulkan permasalahan seperti kejahatan.

Salah satu bentuk kejahatan yang sering terjadi pada lingkungan masyarakat adalah pemalsuan. Kejahatan pemalsuan yang penah terjadi di dalam masyarakat adalah pemalsuan surat. Sedangkan perbuatan memalsukan surat menurut Adami Chazawi dan Ardi Ferdian (2014) mengatakan bahwa perbuatan mengubah dengan cara apapun oleh orang yang tidak berhak terhadap sebuah surat yang menyebabkan sebagian atau seluruh isi surat itu menjadi lain/berbeda dari surat semula atau surat aslinya [1]. Kejahatan pemalsuan adalah kejahatan yang di dalamnya mengandung unsur keadaan sama tapi berbeda dengan aslinya, yang sesuatunya itu tampak dari luar seolah-olah benar adanya padahal sesungguhnya bertentangan dengan yang sebenarnya.

Kejahatan pemalsuan dengan objek pemalsuan surat yang banyak ditemukan di lingkungan masyarakat adalah kejahatan pemalsuan surat kendaraan bermotor. Surat yang biasanya dipalsukan adalah seperti SIM. Yang mana menurut Undang-undang Nomor 22 Tahun 2009 tentang lalu lintas dan angkutan jalan, maka setiap orang yang mengemudikan kendaraan bermotor di jalan wajib memiliki SIM sesuai dengan jenis kendaraan bermotor yang dikemudikan. Dalam hal ini juga nantinya akan adanya sanksi pidana kurungan paling lama 1 (satu) bulan atau denda paling banyak Rp. 250.000,00 (dua ratus lima puluh ribu rupiah) kepada setiap orang yang mengemudikan kendaraan bermotor di jalan yang tidak dapat menunjukkan surat izin mengemudi yang sah.

Pada kenyataan dalam pengurusan dan pembuatan SIM yang ada di wilayah kabupaten Indragiri Hulu Polisi Resort (Polres) Kecamatan Rengat masih terdapat beberapa kendala seperti halnya pada waktu, dimana pada proses pembuatan SIM masih memerlukan waktu yang cukup lama, dari pendaftaran sampai penyerahan SIM memerlukan waktu 5 sampai 6 jam, tergantung banyaknya jumlah pemohon SIM. Masalah berikutnya yaitu pada data SIM dan barcode yang belum di fungsikan oleh pihak kepolisian dan yang paling penting saat petugas melakukan pemeriksaan masih terdapat kendala yaitu untuk mengetahui legalitas SIM pengendara, dimana menurut Kamus Besar Bahasa Indonesia (KBBI) legalitas merupakan suatu keadaan keabsahan, artinya benar adanya. Petugas hanya mengecek masa berlaku dari SIM pengendara, masalah legalitas belum dilakukan karena minimnya alat untuk membuktikan legalitas SIM itu sendiri.

Berdasarkan fakta dari permasalahan tersebut, penelitian ini merealisasikan sebuah sistem deteksi secara real yang mampu membedakan antara SIM asli dan SIM palsu. Sistem ini dibuat dengan menggunakan smartphone sebagai media untuk membaca barcode yang berada pada SIM pengendara dan mobile sebagai software untuk membangun program aplikasi dari sistem yang dibuat. Pada saat proses pengenalan barcode sebagai informasi dan petugas akan membandingkan dengan SIM pengendara. Sistem ini terintegrasi dengan sistem pembuatan SIM.

\section{METODOLOGI PENELITIAN}

Metode penelitian adalah cara dan langkah-langkah yang digunakan dalam melakukan penelitian. Pada penelitian dalam proses pengkajian data mining ini, cara dan langkah-langkah yang digunakan antara lain : Pengumpulan Data, Konsep Teori, dan Perancangan Sistem. Uraian metode penelitian yang digunakan dapat diuraikan sebagai berikut : 


\subsection{Pengumpulan Data}

Dalam melakukan proses kajian data mining, sangat diperlukan sebuah data yang benar, dan terbukti keakuratannya. Maka dari itu, untuk mendapatkan data yang benar dan akurat, teknik pengumpulan data dilakukan dengan cara sebagai berikut :

A. Observasi

Teknik pengumpulan data dengan cara melakukan penelitian langsung ke lokasilokasi terhadap objek yang diteliti.

B. Wawancara

Teknik pengumpulan data dengan sesi tanya jawab dilakukan untuk mendapatkan data dan keterangan secara langsung.

C. Studi Kepustakaan

Melakukan penelitian di perpustakaan dengan cara mencari buku dan literatur yang berhubungan dengan masalah yang di teliti. Hal ini sangat berguna untuk pedoman dan referensi bagi penulis.

\subsection{Konsep Teori}

Teori yang yang digunakan pada penelitian ini dapat diuraikan sebagai berikut :

\subsubsection{Studi Pustaka}

Berdasarkan penelitian yang dilakukan oleh Jati Sasongko (2006), menyatakan bahwa apabila terjadi kerusakan atau kehilangan Kartu Tanda Mahasiswa (KTM) yang jumlahnya sangat sedikit dan waktu yang tidak bersamaan akan mengakibatkan proses pembuatan kartu mahasiswa tidak lagi efektif dan efisien. Untuk menyelesaikan permasalahan tersebut maka akan dibuat aplikasi pencetak kartu mahasiswa dengan menggunakan barcode sebagai identifikasi kartu mahasiswa. Kesimpulan dari penelitian ini adanya sistem pencetak kartu mahasiswa, proses pembuatan KTM yang sangat random dalam masalah jumlah dan waktu dapat teratasi [10].

Penelitian berikutnya yaitu penelitian yang dilakukan oleh Rahmat Purbadi (2013) menyatakan bahwa permasalahan dalam penelitian ini adalah pelayanan pembuatan Surat Izin Mengemudi (SIM) yang dilaksanakan oleh petugas kepolisian tidak sesuai dengan keinginan masyarakat. Disamping itu sikap petugas dalam memberikan pelayanan kurang dapat memelihara hubungan kerja serta menciptakan kepuasan kepada masyarakat yang dilayani, misalnya efesiensi waktu dalam pelayanan, kemudahan pelayanan, dan keadilan pelayanan. Hasil penelitian menunjukan bahwa yang sering dikeluhkan masyarakat adalah lamanya waktu pengurusan SIM karena ada beberapa tahapan yang harus ditempuh oleh pemohon, khususnya dalam pembuatan SIM baru. Untuk menyelesaikan permasalahan tersebut, maka hasil dari penelitian ditemukan bahwa petugas kepolisian telah memiliki rasa tanggung jawab. Hal ini dapat dilihat dari bukti bahwa petugas telah berusaha masuk kerja sesuai dengan jam kerja yang sudah ditentukan oleh Kepolisian Negara Republik Indonesia dalam melaksanakan tugasnya. Kesimpulan dari penelitian yang dilakukan oleh Rahmat Purbadi (2013) adalah bahwa prosedur pelayanan dalam Pembuatan Surat Izin Mengemudi (SIM) di Polresta Pontianak sangat mudah dipahami, namun dalam prosesnya ada beberapa tahapan yang harus ditempuh khususnya bagi pengajuan SIM baru. Dalam prosedurnya pemohon harus melalui beberapa tahapan diantaranya harus lulus ujian teori dan ujian praktek. Dari hasil penelitian menunjukkan bahwa yang sering dikeluhkan masyarakat adalah lamanya waktu pengurusan SIM karena ada beberapa tahapan yang harus ditempuh oleh pemohon, khususnya dalam pembuatan SIM baru [8].

Penelitian berikutnya yaitu penelitian yang dilakukan oleh Fuad Hasan (2015), menjelaskan tentang Museum Sonobudoyo sudah terdapat sistem manajemen koleksi 
museum tetapi hanya orang-orang tertentu yang dapat mengakses sistem tersebut. Untuk menyelesaikan permasalahan tersebut, maka dibutuhkan aplikasi berbasis android untuk menampilkan informasi benda koleksi pamer yang digunakan pemandu dan pengunjung untuk melihat informasi lebih detail tentang benda-benda koleksi pamer. Kesimpulan dari penelitian ini adalah untuk mempermudah pengunjung mengetahui informasi benda koleksi museum maka akan di buat aplikasi berbasis android dengan QR Code Scanner (quick response) [3].

\subsubsection{Surat Izin Mengemudi (SIM)}

SIM adalah kepanjangan dari Surat Izin Mengemudi, walaupun dalam kenyataannya bentuk dari Surat Izin Mengemudi (SIM) tidaklah menyerupai sebuah surat, melainkan sebuah kartu. Mengenai pengertian atau definisi dari SIM menurut Much. Nurachmad (2012) adalah bukti registrasi dan identifikasi yang diberikan oleh Polri kepada seseoraang yang telah memenuhi persyaratan administrasi, sehat jasmani dan rohani, memahami peraturan lalu lintas dan trampil mengemudikan kendaraan bermotor [7].

\subsubsection{Fungsi dan Peranan Surat Izin Mengemudi (SIM)}

1. Sebagai sarana identifikasi / jati diri seseorang

2. Sebagai alat bukti

3. Sebagai sarana upaya paksa

4. Sebagai sarana pelayanan masyarakat Setiap pengemudi kendaraan bermotor wajib memiliki SIM peraturan ini tercantum pada Pasal 18 (1) UU No. $14 \mathrm{Th}$ 1992 tentang Lalu-lintas dan Angkutan Jalan, bahwa setiap pengemudi kendaraan bermotor diwilayah wajib memiliki Surat Ijin Mengemudi (SIM) [7].

\subsubsection{Penggunaan dan Golongan Surat Izin Mengemudi (SIM)}

Pasal 211 (2) PP 44 / 93 [7] : (1) Golongan SIM A, SIM untuk kendaraan bermotor roda 4 dengan berat yang diperbolehkan tidak lebih dari $3.500 \mathrm{Kg}$. (2) Golongan SIM A Khusus, SIM untuk kendaraan bermotor roda 3 dengan karoseri mobil (Kajen VI) yang digunakan untuk angkutan orang / barang (bukan sepeda motor dengan kereta samping). (3) Golongan SIM B1, SIM untuk kendaraan bermotor dengan berat yang diperbolehkan lebih dari $1.000 \mathrm{Kg}$. (4) Golongan SIM B2, SIM untuk kendaraan bermotor yang menggunakan kereta tempelan dengan berat yang diperbolehkan lebih dari $1.000 \mathrm{Kg}$. (5) Golongan SIM C, SIM untuk kendaraan bermotor roda 2 yang dirancang dengan kecepatan lebih dari $40 \mathrm{Km} /$ Jam. (6) Golongan SIM D, SIM khusus bagi pengemudi yang menyandang disabilitas/berkebutuhan khusus.

\section{2.5 Persyaratan Pemohon Surat Izin Mengemudi (SIM)}

Pasal 217 (1) PP 44 / 93[7] : (1) Permohonan tertulis. (2) Bisa membaca dan menulis. (3) Memiliki pengetahuan peraturan lalu lintas jalan dan tekhnik dasar kendaraan bermotor. (4) Batas usia : a) 16 Tahun untuk SIM Golongan C, b) 17 Tahun untuk SIM Golongan A, c) 20 Tahun untuk SIM Golongan BI / BII. (5) Terampil mengemudikan kendaraan bermotor. (6) Sehat jasmani dan rohani. (7) Lulus ujian teori dan praktek.

\section{2.6 Biaya Penerbitan Surat Izin Mengemudi (SIM)}

PP 50/2010 [7] : (1) SIM A : Pembuatan SIM A Baru : Rp 120.000, Perpanjang SIM A: Rp 80.000. (2) SIM B1: Pembuatan SIM B1 Baru : Rp 120.000, Perpanjang SIM B1: Rp 80.000. (3) SIM B2 : Pembuatan SIM B2 Baru : Rp 120.000, Perpanjang SIM B2: Rp 80.000. (4) SIM C : Pembuatan SIM C Baru : Rp 100.000. Perpanjang SIM C: Rp 
75.000. (5) SIM D (Penyandang disabilitas/berkebutuhan khusus) : Pembuatan SIM D Baru : Rp 50.000, Perpanjang SIM D: Rp 30.000. (6) SIM Internasional : Pembuatan SIM Internasional Baru : Rp 250.000, Perpanjang SIM Internasional: Rp 225.000.

\section{2.7 Prosedur Pembuatan SIM Baru}

Prosedur Pembuatan SIM baru : (1) Mengajukan permohonan secara tertulis. (2) Membayar biaya melalui Bank. (3) Melakukan registrasi dengan cara : mengisi formulir, melampirkan persyaratan administrative, tanda tangan, pengambilan 10 sidik jari, foto yang akan dietak pada SIM. (4) Melakukan ujian teori. (5) Melakukan ujian praktek. (6) Pencetakan SIM [7].

\subsection{Prosedur Perpanjangan SIM}

Prosedur Perpanjangan SIM : (1) Mengisi formulir. (2) Menunjukan KTP asli dan menyerahkan fotocopy KTP. (3) Membawa SIM lama. (4) Membawa surat keterangan sehat dokter (sehat jasmani dan rohani). (5) Bagi pemegang SIM yang telah lewat masa berlakunya lebih dari satu tahun harus mengikuti ujian teori dan praktek [7].

\subsubsection{Barcode (Kode Batang)}

Barcode adalah suatu sistem pengkodean dalam bentuk garis vertikal hitam dan putih dengan ketebalan yang berbeda, dimana setiap garis menunjukan kode tertentu. Barcode juga merupakan suatu teknologi identifikasi otomatis yang sangat sederhana, pengambilan datanya dilakukan dengan lebih cepat dan lebih akurat. Barcode scanner marupakan hardware yang menghubungkan kode bar (barcode) dengan komputer dan menerjemahkannya dalam bentuk angka/karakter yang bisa dikenali oleh sebuah aplikasi. Menurut Ruri Hartika Zain (2010) barcode scanner atau barcode reader umumnya digunakan oleh toko-toko, perusahaan, rumah sakit, perpustakaan dan lain-lain [2].

\subsubsection{Konsep Mobile}

Mobile dapat diartikan sebagai perpindahan yang mudah dari satu tempat ke tempat yang lain, misalnya telepon mobile berarti bahwa terminal telepon yang dapat berpindah dengan mudah dari satu tempat ke tempat lain tanpa terjadi pemutusan atau terputusnya komunikasi. Sistem aplikasi mobile merupakan aplikasi yang dapat digunakan walaupun pengguna berpindah dengan mudah dari satu tempat ketempat lain lain tanpa terjadi pemutusan atau terputusnya komunikasi. Aplikasi ini dapat diakses melalui perangkat nirkabel seperti pager, seperti telepon seluler dan PDA.

\subsubsection{JQuery Mobile}

Sejak dirilis pertama kali pada tahun 2006 oleh John Resig, JQuery Mobile semakin banyak digunakan untuk website dan semakin populer terutama dipakai untuk smartphone dan tablet. JQuery Mobile pada prinsipnya adalah sebuah web framework atau bingkai kerja siap pakai yang ramah untuk gadget dengan desain layar sentuh. Framework sendiri intinya adalah sebuah format siap pakai yang bisa Anda gunakan untuk desain website Anda sehingga Anda tidak direpotkan dengan banyak kode dan fungsi yang memusingkan. Menggunakan JQuery Mobile sebagai framework dalam website Anda bisa membuat website Anda lebih interaktif.

\subsubsection{PHP (Hypertext Preprocessor)}

Menurut Abdul Kadir (2003) PHP adalah skrip yang dijadikan di server. Jadi konsepnya berbeda dengan JavaSkript, yang dijadikan di klien [4]. Keuntungan penggunaan PHP, kode yang menyusun program tidak perlu diedarkan ke pemakai sehinnga kerasahiaan kode dapat dilindungi. 


\section{PEMBAHASAN}

\subsection{Pengembangan Sistem}

Sistem ini akan mempermudah petugas kepolisian pada saat pembuatan SIM yang baru maupun perpanjangan. Sedangkan bagi pengendara, sistem ini bisa mengifisiensi waktu dan mempercepat proses pembuatan SIM tergantung banyaknya antrian pada saat pembuatan SIM yang baru maupun perpanjangan. Petugas kepolisian yang melakukan penegakkan hukum dijalan, sistem ini akan membantu dalam proses legalitas SIM pengendara. Sistem ini menggantikan sistem manual menjadi lebih terkomputerisasi. Oleh karena itu disini akan diuraikan bentuk pengembangan dan perancangan aplikasi legalitas surat izin mengemudi (SIM) berbasis mobile, sebagai berikut :

1. Pembuatan Surat Izin Mengemudi (SIM)

Ini adalah sistem mengembangkan yaitu pembutan dari SIM. Pada sistem ini petugas kepolisian dapat membuat SIM yang baru maupun perpanjangan. Ketika petugas kepolisian membuat SIM perpanjangan akan lebih terbantu tanpa menginput ulang identitas dari pengendara dan untuk sistem ini sudah memfungsikan barcode yang berada pada SIM.

2. Melihat Laporan SIM Pengendara Tahunan

Kepala polisi dan Kepala Satuan Lalu-lintas (Kasatlantas) dapat melihat laporan SIM pengendara tahunan, mulai dari bulan januari sampai dengan bulan desember, dilaporan SIM pengendara tahunan ini akan di informasikan berapa jumlah dan total SIM pengendara dari golongan A, A Umum, BI, BI Umum, BII, BII Umum, C dan D.

3. Melihat Laporan Identitas SIM Pengendara Tahunan

Kepala polisi dan Kepala Satuan Lalu-lintas (Kasatlantas) dapat melihat laporan identitas SIM pengendara tahunan, dilaporan ini menginformasikan identitas dari SIM pengendara per tahun mulai dari nama, alamat, tempat dan tanggal lahir, pekerjaan, golongan SIM, nomor SIM, tanggal terbit, dan masa berlaku dari SIM tersebut.

4. Melihat Laporan Identitas SIM Pengendara Per Periode

Kepala polisi dan Kepala Satuan Lalu-lintas (Kasatlantas) dapat melihat laporan identitas SIM pengendara Per Periode, ketika pihak kepolisian ingin mengetahui laporan identitas SIM pengendara per periode, maka pihak kepolisian dapat mencetak laporan SIM pengendara per periode.

5. Pengecekan Legalitas SIM Pengendara

Ini adalah sistem membangun yaitu pengecekan legalitas SIM pengendara, sistem ini digunakan oleh Satuan Lalu-lintas (Satlantas) ketika melakukan penegakkan hukum dijalan, sistem ini berfungsi untuk mengetahui keaslian dari SIM pengendara. Sistem ini dibuat dengan menggunakan Smartphone sebagai media untuk membaca barcode yang berada pada SIM pengendara, pada saat proses scanning barcode dapat memberikan informasi legalitas SIM pengendara.

Penjelasan skema proses data mining dijabarkan sebagai berikut :

\section{A. Context Diagram}

Context diagram merupakan gambaran sistem secara umum dan keterkaitan entitas serta data yang mengalir diantaranya. Gambar 1 adalah rancangan context diagram pada sistem ini. 


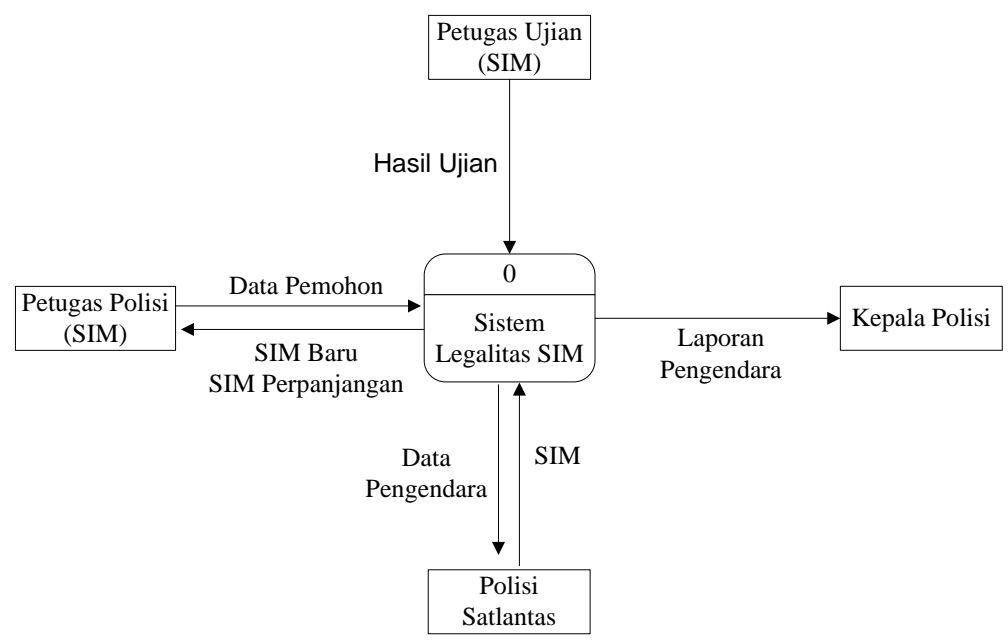

\section{Gambar 1. Context Diagram Legalitas Surat Izin Mengemudi (SIM)}

\section{B. Data Flow Diagram (DFD) Level 0}

DFD level 0 merupakan representasi dari data context diagram yang sudah dipartisi untuk memberikan penjelasan yang lebih detail. Pada sistem ini terdapat 3 proses yaitu proses pengolahan data Surat Izin Mengemudi (SIM), pengolahan legalitas, dan pembuatan laporan. Gambar 2 adalah gambaran DFD level 0 pada sistem ini.

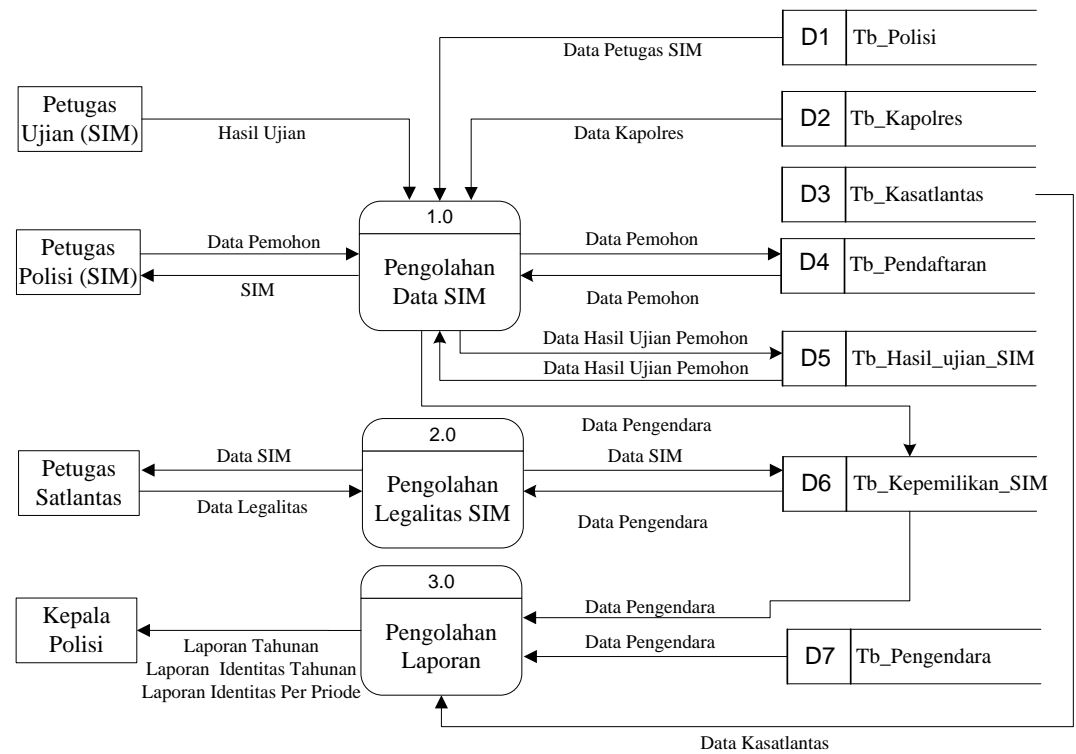

\section{Gambar 2. DFD Level 0 Legalitas Surat Izin Mengemudi (SIM)}

\section{DFD Level 1 Proses 1}

DFD level 1 Proses 1 merupakan penjabaran yang lebih detail dari proses pengolahan data SIM Pada tahap ini terdiri dari 2 proses yaitu proses pembuatan SIM 
baru, dan proses pembuatan SIM perpanjangan. Gambar 3 adalah gambaran DFD level 1 proses 1 pada sistem ini.

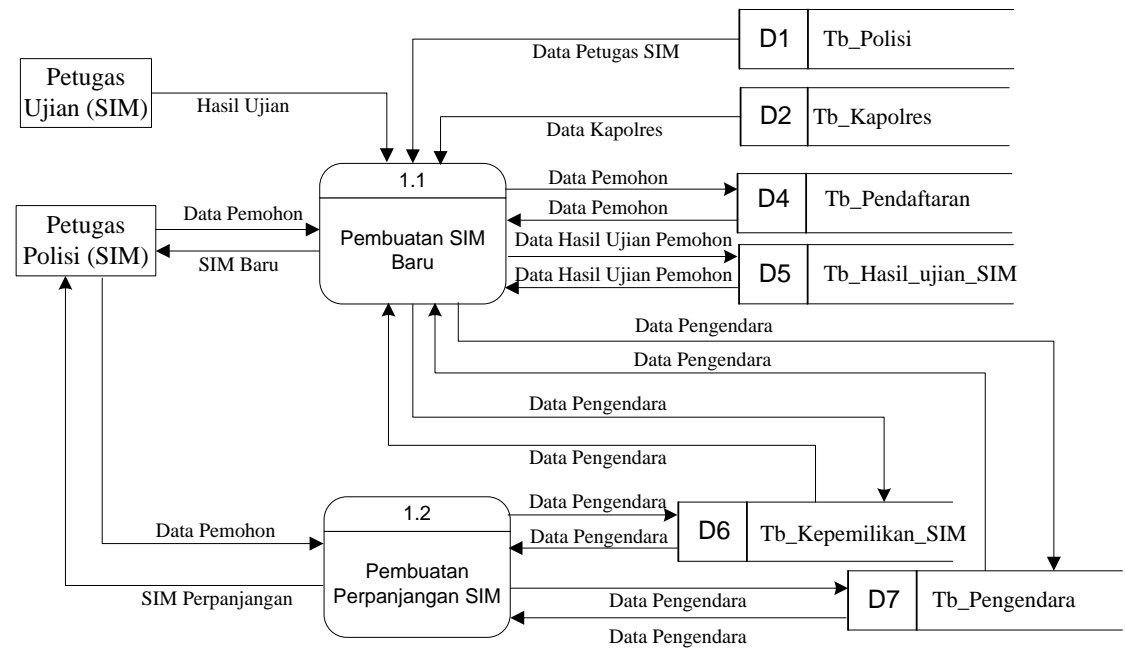

Gambar 3. DFD Level 1 Proses 1 Legalitas Surat Izin Mengemudi (SIM)

D. DFD Level 1 Proses 3

DFD level 1 Proses 3 merupakan penjabaran yang lebih detail dari proses pengolahan laporan. Pada tahap ini terdiri dari 3 proses yaitu proses pembuatan laporan SIM pengendara tahunan, pembuatan laporan identitas SIM pengendara tahunan, dan pembuatan laporan SIM pengendara per periode. Gambar 4 adalah gambaran DFD level 1 proses 3 pada sistem ini.

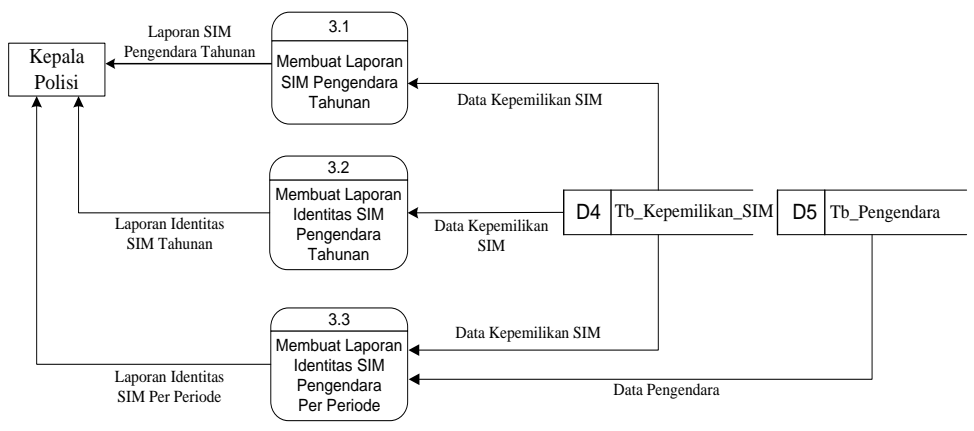

Gambar 4. DFD Level 1 Proses 3 Legalitas Surat Izin Mengemudi (SIM)

\subsection{Perancangan Sistem}

A. ERD (Entity Relationship Diagram)

ERD merupakan suatu model untuk menjelaskan hubungan antar data dalam basis data berdasarkan objek-objek dasar data yang mempunyai hubungan antar relasi. Gambar 5 adalah rancangan ERD dalam sistem ini. 


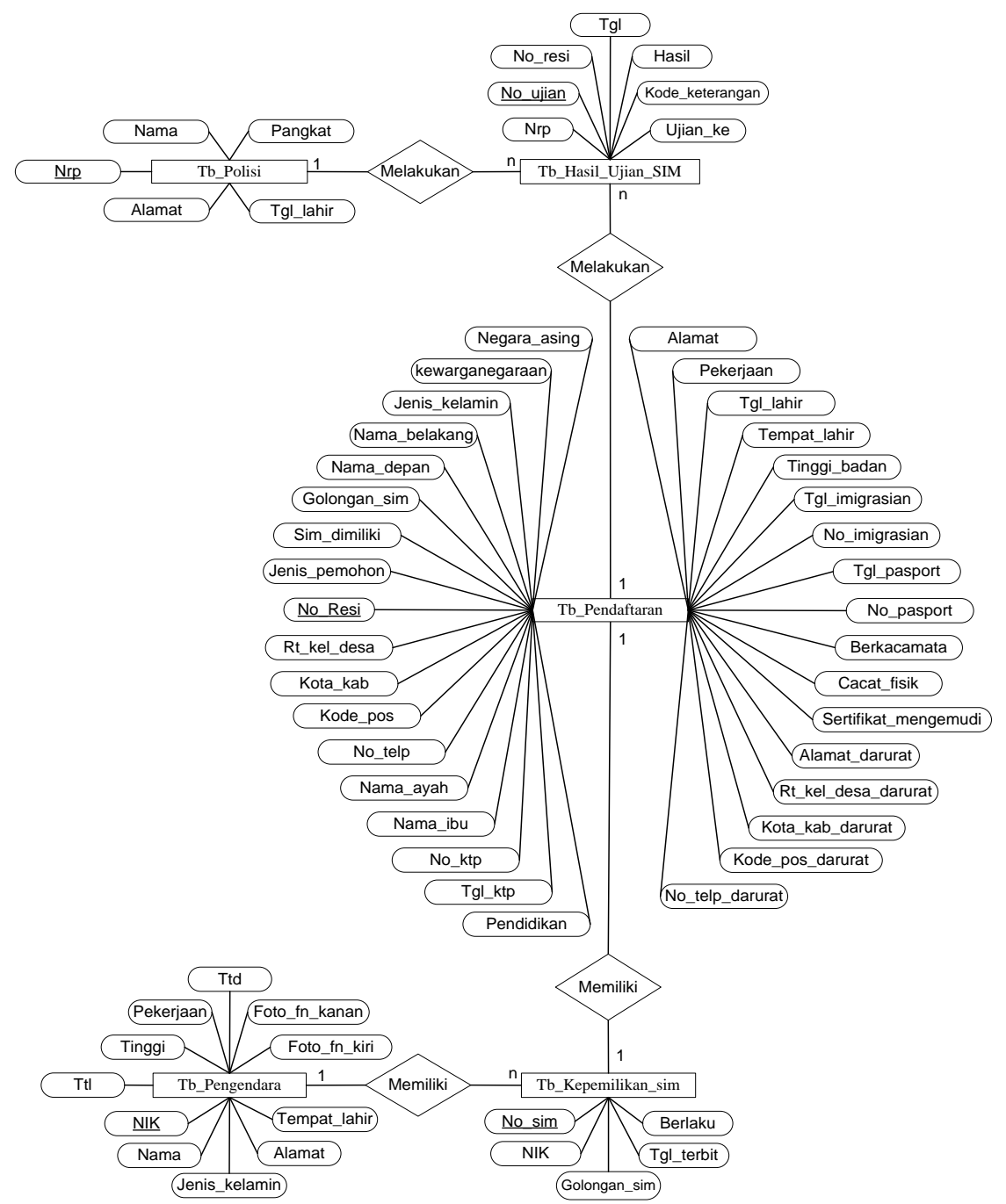

Gambar 5. ERD Legalitas surat Izin Mengemudi (SIM)

\subsection{Hasil Sistem}

Pada sistem legalitas SIM terdapat beberapa modul yaitu home, data master, data pendaftaran SIM, data hasil ujian SIM, kepemilikan SIM, pengendara, report dan legalitas.

Penelitian yang dilakukan adalah mengembangkan sistem. Pengembangan yaitu memfungsikan barcode pada SIM pengendara yang belum difungsikan oleh pihak kepolisian, bertujuan untuk mengetahuhui keabsahan dari SIM pengendara ketika pihak kepolisian melakukan penegakkan hukum dijalan. Hasil dari sistem seperti pada gambar 6 dan gambar 7 . 


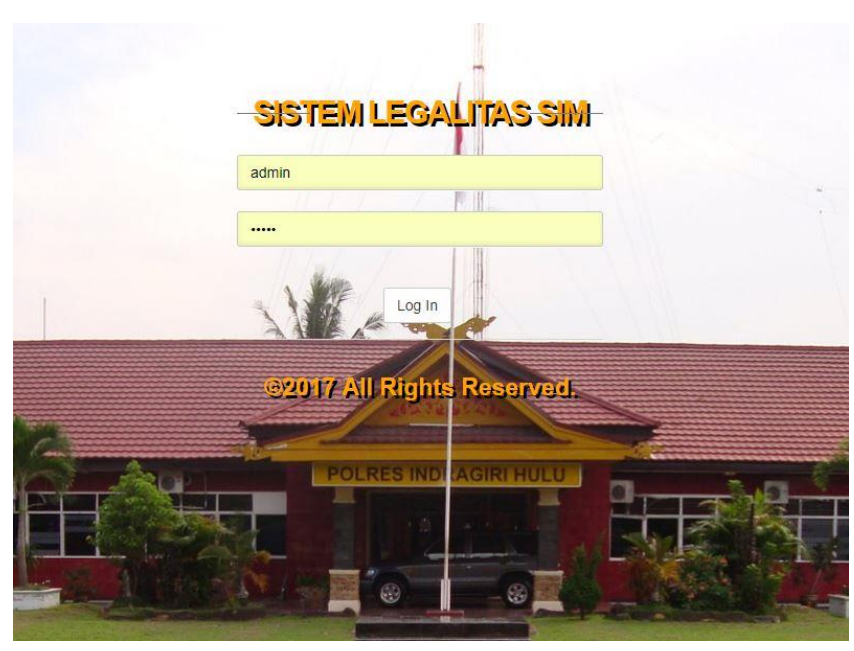

Gambar 6. Tampilan Login Sitem Legalitas SIM

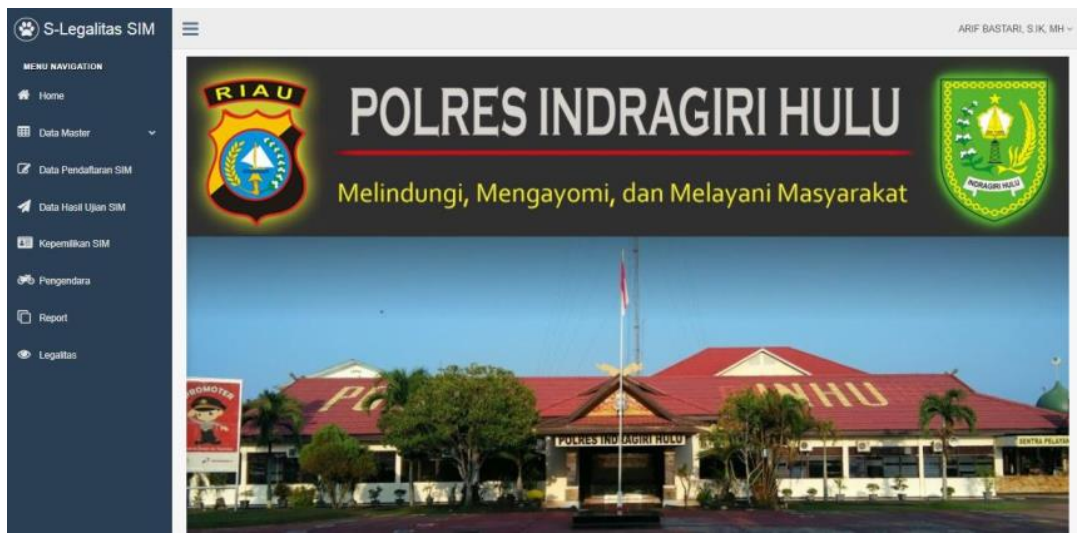

Gambar 7. Tampilan Menu Utama Sitem Legalitas SIM

\section{KESIMPULAN}

Berdasarkan hasil analisa dan perancangan sistem, implementasi dan pengujian sistem, maka dapat disimpulkan bahwa :

1. Aplikasi legalitas Surat Izin Mengemudi (SIM) berbasis mobile ini memberikan informasi legalitas SIM pengendara.

2. Aplikasi ini dapat mempercepat dalam melakukan proses pembuatan SIM baru maupun perpanjangan SIM dengan memerlukan waktu range 1 sampai 2 jam, tergantung banyaknya jumlah pemohon SIM.

3. Aplikasi legalitas Surat Izin Mengemudi (SIM) berbasis mobile ini dapat membantu pihak kepolisian ketika melakukan pemeriksaan legalitas SIM pengendara.

4. Berdasarkan pengujian terhadap sistem legalitas SIM diperoleh hasil 84\%, sehingga aplikasi ini layak untuk digunakan. 


\section{SARAN}

Dari kesimpulan yang ada, maka dapat dikemukakan saran-saran yang akan sangat membantu untuk pengembangan perangkat lunak ini selanjutnya:

1. Diharapkan kedepannya sistem ini bisa diintegrasikan dengan E-KTP, sehingga pada saat pengisian biodata bisa lebih cepat dan mempermudah pihak kepolisian.

2. Diharapkan kedepannya sistem ini bisa dikembangkan dengan E-Tilang, sehingga penilangan SIM akan lebih cepat dan terbantu.

\section{DAFTAR PUSTAKA}

[1] Chazawi, Adami dan Ferdian, Ardi., 2014, "Tindak Pidana Pemalsuan“, PT.Raja Grafindo Persada, Jakarta.

[2] Hartika, Ruri, Zain, 2010, "Pembaca Identitas Kartu Barcode dengan Memanfaatkan Scanner Barcode Untuk Memasuki Ruangan Pustaka Dengan Menggunakan Bahasa Pemrograman Borland Delphi 7.0", Jurnal STIKOM Dinamika Bangsa, Vol. 5, No. 1, Februari 2010.

[3] Hasan, Fuad, 2015, "Pemanfaatan QR Scanner Untuk Aplikasi Penampilan Data Koleksi Pamer di Museum Negeri Sonobudoyo Berbasis Android", Skripsi Teknik Informatika, Universitas Islam Negeri Sunan Kalijaga, Yogyakarta.

[4] Kadir, Abdul, 2003, Mencakup: Html Css Javascript \& Php, Andi, Yogyakarta.

[5] Kadir, Abdul, 2009, Membuat Aplikasi Web dengan PHP dan Database MySql, Andi Offset, Yogyakarta.

[6] Nugroho, Bumafit, 2005, Database Relasional dengan MySql, Andi, Yogyakarta.

[7] Nurachmad, Much, 2012, Pedoman Mengurus Segala Macam Surat Perizinan \& Dokumen Secara Legal Formal, Pustaka Yustisia, Yogyakarta.

[8] Purbadi, Rahmat, 2013, Pelayanan Surat Izin Mengemudi di Kepolisian Resort Kota Pontiak, Jurnal S-1 Ilmu Administrasi Negara, Volume 2, Nomor 2, Agustus 2003.

[9] Republik Indonesia, 2009, Undang-Undang R.I Nomor 22 Tahun 2009 Tentang Lalulintas dan Angkutan Jalan, Citra Umbara, Bandung.

[10] Sasongko, Jati, 2006, Rancang Bangun Program Aplikasi Pencetak Kartu Mahasiswa, Jurnal Teknologi Informasi DINAMIK, Volume XI, No.1, Januari 2006.

[11] Sutabri, Tata, 2012, Analisis Sistem Informasi, Andi, Yogyakarta.

[12] Kepolisian Negara Republik Indonesia., 2016, https://www.polri.go.id/ Diakses Pada Tanggal 20 November 2016. 